\title{
PENDAYAGUNAAN FREIES ERMESSEN PEJABAT PEMERINTAHAN DALAM KONSEP NEGARA KESEJAHTERAAN
}

\author{
Dyah Adriantini Sintha Dewi \\ Fakultas Hukum Universitas Muhammadiyah Magelang \\ Email: dyahadriantini@yahoo.com
}

\begin{abstract}
Freies ermessen is the authority freegiven to government officials in order to provide the best service for citizens, which is a consequence of the concept of the welfare state aimed at the welfare of society. In this case, there is principle that government should not refuse to solve a problem with no reason or no rules, so that the public interest is not harmed, officials were given the authority to interpret and apply its own rule for resolving the problems faced by the community. However, to avoid irregularities freies ermessen then it must comply with the general principles of good governance and required their means of control, control of the judicial, political and administrative.
\end{abstract}

Key Words:Freies ermessen, officials, the welfare state

\begin{abstract}
Abstrak
Freies ermessen merupakan kewenangan bebas yang diberikan kepada pejabat pemerintahan dalam rangka memberikan pelayanan yang terbaik bagi warga masyarakat, yang merupakan konsekuensi dari adanya konsep negara kesejahteraan (welfarestate) yang bertujuan untuk mensejahterakan masyarakat. Dalam hal ini dikenal adanya prinsip bahwa pemerintah tidak boleh menolak untuk menyelesaikan suatu masalah dengan alasan tidak atau belum ada aturannya, sehingga agar kepentingan masyarakat tidak dirugikan, pejabat diberi kewenangan untuk menafsirkan dan menerapkan sendiri suatu aturan untuk menyelesaiakan masalah yang dihadapi oleh masyarakat. Namun demikian, untuk menghindari penyim-pangan maka freies ermessen itu harus sesuai dengan asasasas umum pemerintahan yang baik serta diperlukan adanya sarana kontrol, baik kontrol yudisial, politik maupun administratif.
\end{abstract}

Kata Kunci: freies ermessen, pejabat, negara kesejahteraan

\section{A. Pendahuluan}

Alinea ke empat Pembukaan Undang-Undang Dasar Negara Republik Indonesia menerangkan bahwa salah satu tujuan dibentuknya negara Indonesia adalah untuk memajukan kesejahteraan umum dan mencerdaskan kehidupan bangsa. Istilah kesejahteraan ini harus diartikan secara luas yang mencakup segala aspek kehidupan bangsa Indonesia yang nantinya akan berimbas pada kesejahteraan seluruh umat manusia di dunia ini. Semangat inilah yang menginspirasi bangsa Indonesia dan selajutnya menuangkanya dalam pelaksanan pemerintahan mendasarkan pada konsep negara kesejahteraan (welfare state), yang mana banyak dari urusan masyarakat yang pada akhirnya ditangani oleh fihak pemerintah. Pemerintah masuk ikut serta 
menangani dengan maksud agar tidak menimbulkan kerugian bagi masyarakat. seperti misalnya, berkait dengan masalah perburuhan, jika hal tersebut pengaturannya hanya diserahkan kepada para pihak, yaitu pemberi kerja dan pekerja semata, maka sangat mungkin terjadi ketidakadilan. Di satu sisi bisa saja terjadi, pemberi kerja akan menekan pekerja melalui standar upah yang rendah, atau sebaliknya, pekerja memasang tarif upah yang terlalu tinggi. Jika kondisi seperti ini dibiarkan, maka akan menimbulkan kerugian pada salah satu pihak. Inilah saatnya pemerintah masuk untuk menegakkan keadilan dan melindungi warga negara sesuai dengan tugas utamanya. Masuknya pemerintah ke dalam urusan masyarakat tersebut melalui pembuatan peraturan di bidang perburuan merupakan salah satu konsekuensi dari konsep negara kesejahteraan.

Ditinjau dari sudut ketatanegaraan, keberadaan konsep negara kesejahteraan dengan tujuannya untuk memberikan kesejahteraan bagi seluruh warga negara, adalah dalam rangka untuk melengkapi asas legalitas yang mana semua.

Aktivitas pemerintahan harus mendasarkan kepada peraturan perundangan. Sementara itu, dengan berkembangnya ilmu pengetahuan dan tekhnologi, maka sangat mungkin mempengaruhi pula terhadap dinamika perkembangan masyarakat dengan berbagai aktivitasnya, yang mana sangat mungkin terjadi untuk menangani masalah yang timbul, belum ada peraturannya. Di sinilah karakteristik konsep Negara Kesejahteraan, yaitu memberikan kewenangan berupa freies ermessen atau diskresi, sebagai salah satu keputusan administrasi,kepada penyelenggara pemerintahan. Hal ini sesuai pendapat dari Prajudi Atmosudirdjo, bahwa dalam asas diskresi (discretie, freies ermessen), pejabat penguasa tidak boleh menolak mengambil keputusan dengan alasan "tidak ada peraturannya", untuk itu maka kepadanya diberi kebebasan untuk memutuskan berdasarkan pendapatnya sendiri sepanjang tidak melanggar asas yuriditas dan asas legalitas (Prajudi Atmosudirdjo, 1981; 95).

Keleluasaan pejabat pemerintahan yang berdasarkan diskresi diharapkan menjadi pintu masuk bagi terwujudnya kesejahteraan masyarakat, mengingat proses penyelesaian masalah masyarakat bisa menjadi lebih cepat.

\section{B. Rumusan Masalah}

Tulisan ini bermaksud untuk menganalis pelaksanaan freies ermessen oleh pejabat pemerintahan berdasarkan peraturan perundangan yang berlaku dengan memberikan pemahaman agar tidak terjadi tindakan sewenang-wenang atas diberikannya freies ermessen tersebut.

\section{Pembahasan}

\section{Sejarah Negara Kesejahteraan}

Konsep negara hukum, baik itu rechtstaatyang berkembang di negara-negara Eropah Kontinental yang bertumpu pada sistem hukum kontinentalyang disebut civil law atau 
Modern Roman Lawdengan tokohnya Freidrich Julius Stahl,maupun konsep the rule of law yang berkembang di area Anglo Saxon,dengan tokohnya A.V. Dicey yang bertumpu pada sistem hukum common lawdalam perkembangannya telah muncul reaksi terhadap falsafah laisssez faire (Saut S Panjaitan: 105) atau prinsip "pemerintah yang paling baik adalah yang memerintah sesedikit mungkin" yang mana hal ini adalah yang dipegang teguh oleh ajaran “negara penjaga malam' (nachtwachtersstaat). Reaksi ini diwujudkan dengan munculnya negara kesejahteraan yaitu konsep pemerintahan di mana suatu negara memegang peranan kunci dalam perlindungan dan pemajuan kesejahteraan ekonomi dan sosial warganya(I Dewa Gede Palguna, 2008: 185). Dengan demikian, tidak merupakan jaminan bahwa sedikit yang memerintah akan membawa kebaikan masyarakat, jika memang kenyataanya semakin banyak permasalahan masyarakat yang menghendaki untuk adanya campur tangan lebih banyak dari pemerintah, sebagaimana alasan munculnya negara kesejahteraan, yaitu alasan ekonomis dan politis.

Alasan ekonomis mendasarkan pada adanya kenyataan bahwa dalam masyarakat modern sekarang ini makin banyak orang yang menggantungkan hidupnya pada orang lain sebagai pekerja, dan pada akhirnya akan berpengaruh pada bidang politik, yaitu tuntutan agar negara melakukan hal-hal yang dulu dilakukan oleh masyarakat sendiri (I Dewa Gede Palguna, 2008: 185).

Friedmann dalam bukunya The Rule of Law and The Welfare State menyebutkan 5 (lima) fungsi dari negara kesejahteraan, yaitu sebagai protector, provider, regulator, enterpreuner, arbitrator yang di dalam penerapannya ternyata berbeda-beda untuk masingmasing negara. Hal ini sejalan dengan pendapat Gôsta Esping-Andersen yang menggolongkan negara kesejahteraan mejadi 3 (tiga), yaitu ((I Dewa Gede Palguna, 2008: 185):

a. Anglo-Saxon welfare states, meliputi Amerika Serikat, Inggris, Selandia baru, Australia, yang mencerminkan komitmen-komitmen politik untuk m e m p e r k e c i 1 peran, negara , mengindividualisasikan risiko-risiko, dan memajukan penyelesaian-penyelesaian melalui mekanisme pasar terhadap masalah-masalah kesejahteraan warganya.

b. Scandinavian welfare states, diikuti oleh Swedia, Norwegia, Denmark yang memiliki komitmen kuat untuk melakukan cakupan kesejahteraan warganya secara menyeluruh.

\section{Freies Ermessen sebagai konsekuensi Negara Kesejahteraan}

Banyaknya permasalahan yang dihadapi oleh warga masyarakat, di mana sudah menjadi kewajiban bagi pemerintah untuk memberikan pelayanan yang terbaik sebagai konsekuensi 
kepercayaan masyarakat kepada pemerintah melalui kinerja para pejabat, maka adanya freies ermessen menjadi hal yang tidak terelakkan lagi keberadaannya. Hal ini adalah selaras dengan tujuan utama dari Hukum Administrasi Negara, sebagaimana disampaikan oleh Sir William Wade dan Christopher Forsyth sebagaimana dikutip oleh Ridwan, yaitu menjaga kekuasaan pemerintah dalam batas-batasnya, untuk melindungi warga negara dari penyalahgunaan kekuasaan. Sekalipun melalui freies ermessen tersebut, pemerintah melalui para pejabatnya diperkenankan untuk menentukan sendiri baik itu cara maupun penerapan peraturannya, namun tindakan tersebut tetap harus ada pembatasannya karena ini berkait dengan masalah pertanggungjawaban kepada masyarakat (Ridwan, 2014: 191).

Dalam penerapannya, terhadap freies ermessen tersebut tetap harus berpegang pada aturan yang tidak boleh menimbulkan kerugian bagi masyarakat. Untuk menghindari tindakan yang sewenang-wenang dari pejabat dengan alasan dimilikinya freies ermessen, maka terdapat 3 (tiga) hal pokok yang melekat pada freies ermessen tersebut, yaitu (Saut S Panjaitan: 105):

a. Adanya kebebasan bagi pejabat untuk bertindak atas inisiatif sendiri. Ketentuan ini tidak berarti bahwa kebebasan tersebut adalah tanpa batas, namun adalah dalam batas-batas yang telah ditentukan oleh peraturan perundang-undangan ; atau dengan cara memilih salah satu alternatif sebagaimana tercantum dalam undng-undang.

b. Untuk menyelesaiakan persoalan-persoalan yang mendesak namun belum ada aturannya, dengan kriteria sebagaimana dikemukakan oleh Markus Lukman, hal tersebut merupakan persoalan yang menyangkut kepentingan umum, muncul secara tiba-tiba di luar rencana awal, belum ada peraturan yang mengaturnya, prosedurnya tidak dapat diselesaikan menurut administrasi yang normal, persoalan tersebut harus segera mendapat penyelesaian.

c. Harus dapat dipertanggung jawabkan. Berkait dengan penerapan freies ermessen, perlu diperhatikan adanya tanggung jawab secara hukum, sehingga tidak boleh beretentangan dengan peraturan perundang-undangan, harus mempertimbangan hak dan kepentinan warga negara, serta harus sesuai dengan tujuan pemberian wewenang tersebut (Ridwan, 2014: 192).

Batasan sebagaimana diuraikan di atas merupakan wujud dari konsep dasar negara hukum yang melandasai welfare state, artinya sekalipun dalam konsep welfare state dimungkinkan banyaknya campur tangan pemerintah terhadap urusan masyarakat, namun sebagai negara hukum tetap harus patuh terhadap kerangka dasar yaitu dengan tetap memperhatikan peraturan perundangan yang berlaku, sehinga tindakan tersebut tidak menjadi liar dan merugikan masyarakat. Sebab, jika hal tersebut yang terjadi, maka jelas freies ermessen yang dimaksudkan 
untuk mensejahterakan masyarakat dengan misalnya penyelesaian secara cepat, ujung-ujungnya justru menimbulkan kesengsaraan masyarakat.

Berkait dengan hal tersebut, Sjachran Basah sebagaimana dikutip oleh Ridwan HR, mengemukakan adanya unsur-unsur yang harus dipenuhi dalam pelaksanaan freies ermessen di dalam sebuah negara hukum, yaitu (Ridwan, 2014: 192).

a. Ditujukan untuk menjalankan tugas-tugas servis publik.

b. Merupakan sikap tindak yang aktif dari administrasi negara.

c. Sikap tindak itu dimungkinkan oleh hukum.

d. Sikap tindak itu diambil atas inisiatif sendiri.

Atas dasar unsur-unsur tersebut, terlihat bahwa walaupun freies ermessen itu merupakan sebuah wewenang bebas, namun tetap ada batasannya sesuai dengan konsep negara hukum yang dimaksudkan untuk memberikan rasa adil dan nyaman bagi warga masyarakat.

Istilah freies ermessen adalah istilah yang dikenal di Jerman, sebagaimana di Inggris dijumpai discretionary power, Belanda memakai istilah beleidsregels, kemudian di Perancis orang mengenal dengan istilah discretionare, dan di Indonesia diartikan sebagai kebijakan namun ada pula yang mengartikannya sebagai kebijaksanaan. Freies ermessen berasal dari kata "freie" yang berarti "bebas, merdeka, tidak terikat", sehingga "freies" sama dengan "orang bebas". Sementara itu, kata "ermessen" berarti "mempertimbangkan, menilai, menduga dan memutuskan.” Dengan demikian freies ermessen adalah orang yang bebas, merdeka dan tidak terkait dalam menduga, menilai serta mempertimbangkan suatu keputusan (S.F Marbun, 2012: 173).

Dalam rangka untuk menghindari tindakan yang sewenang-wenang dari pejabat yang memiliki sebuah kewenangan untuk mengeluarkan freies ermessen akibat dari jabatan yang diembannya, karena yang memiliki kewenangan adalah jabatan bukan pejabat (Ridwan, 2014: 9), maka rambu-rambu pembatas menjadi hal yang penting supaya tidak masuk dalam ranah maladministrasi. Maldaministrasi sebagaimana diuraikan dalam Pasal 1 angka 3 UndangUndang Nomor 37 Tahun 2008 tentang Ombudsman Republik Indonesia adalah :

"Perilaku atau perbuatan melawan hukum, melampaui wewenang, menggunakan wewenang untuk tujuan lain dari yang menjadi tujuan wewenang tersebut, termasuk kelalaian atau pengabaian kewajiban hukum dalam penyelenggaraan pelayanan publik yang dilakukan oleh Penyelenggara Negara dan pemerintahan yang menimbulkan kerugian materiil dan/atau immaterial bagi masyarakat dan orang perseorangan."

Maladministrasi yang dilakukan oleh pejabat sangat merugikan bagi warga masyarakat, untuk itulah dalam rangka menuju good governance, pemerintah Indonesia telah mengesahkan 
Undang-undang Nomor 37 Tahun 2008 tentang Ombudsman Republik Indonesia. Melalui undang-undang tersebut maka lahirlah lembaga pengawasan yang khusus di bidang pelayanan publik yaitu berkait maladministrasi. Pasal 2 Undang-Undang Nomor 37 Tahun 2008 tentang Ombudsman Republik Indonesia menyatakan, bahwa:

"Ombudsman merupakan lembaga negara yang bersifat mandiri dan tidak memiliki hubungan organik dengan lembaga negara dan instansi pemerintahan lainnya, serta dalam menjalankan tugas dan wewenangnya bebas dari campur tangan kekuasaan lainnya."

Tugas Ombudsman dalam pengawasan terhadap maladministrasi, yang mana maladministrasi yang dilakukan oleh para pejabat dapat dikategorikan ke dalam red tape, yaitu bureaupathologis ataupenyakit birokrasi yang berkaitan dengan penyelenggaraan pelayanan yang berbelit-belit, memakan waktu lama, meski sebenarnya bisa diselesaiakan secara singkat (Hendra Nurtjahjo, dkk, 2013: 12-13).

Freies ermessen dalam pelaksanaanya sangat dimungkinkan untuk terjadinya maladministrasi jika hal tersebut tidak dikawal dengan rambu- rambu pembatas, sekalipun kelahiran freies ermessen itu sendiri adalah dalam rangka untuk untuk melengkapi asas legalitas dalam konsep negara hukum. Adalah hal yang sangat ironis, jika dengan freies ermessen yang dimaksudkan untuk menyelesaikan masalah yang dihadapi warga masyarakat menuju kepada kesejahteraan justru menimbulkan masalah baru berupa kerugian akibat tindakan sewenang-wenang dengan mendasarkan pada pemikiran makna "kebebasan" yang diberikan oleh freies ermessen tersebut.

\section{Pendayagunaan Freies Ermessen Pejabat Pemerintahan di Indonesia}

Tujuan unt uk m ensejaht er ak an masyarakat melalui freies ermessen yang melekat pada sebuah jabatan, dan akhirnya jabatan tersebut akan diemban oleh seorang pejabat, maka dalam pelaksanaannya tetap harus mendasarkan pada adanya pertanggungjawaban atas freies ermessen tersebut. Untuk itu, maka khusus tentang masalah freies ermessen, di mana Undang-Undang Nomor 30 Tahun 2014 tentang Administrasi Pemerintahan menyebut dengan istilah "diskresi" telah mengatur hal tersebut yaitu dalam BAB IV. Dalam Pasal 22 Undang-Undang Nomor 30 Tahun 2014 tentang Administrasi Pemerintahan, disebutkan bahwa diskresi hanya dapat dilakukan oleh Pejabat Pemerintahan yang berwenang dengan tujuan untuk:
a. Melancarkan penyelenggaraan pemerintahan.
b. Mengisi kekosongan hukum.
c. Memberikan kepastian hukum. 
d. Mengatasi stagnasi pemerintahan dalam keadaan tertentu guna kemanfaatan dan kepentingan umum.

Selanjutnya, Pasal 23 Undang-Undang Nomor 30 Tahun 2014 tentang Administrasi Pemerintahan menjelaskan bahwa ruang lingkup diskresi adalah:

a. Pengambilan Keputusan dan/ atau Tindakan berdasarkan ket ent uan peraturan perundang-undangan yang memberikan suatu pilihan Keputusan dan/ atau Tindakan.

b. Pengambilan Keputusan dan/ atau Tindakan karena peraturan perundang-undangan tidak mengatur.

c. Pengambilan Keputusan dan/ atau Tindakan karena peraturan perundang-undagan tidak lengkap atau tidak jelas; dan

d. Pengambilan Keputusan dan/ atau Tindakan karena adanya stagnasi pemerintahan guna kepentingan yang lebih luas.

Dengan demikian jelas bahwa sekaliun freies ermessen atau diskresi diperbolehkan, namun hal tersebut adalah dalam kondisi yang telah ditentukan. Sebagai contoh, misalnya jika dalam suatu wilayah terjadi adanya bencana alam, wabah penyakit, maupun konflik sosial maka sangat dimungkinkan untuk dipergunakan freies ermessen.

Hal lain yang wajib diperhatikan dalam pendayagunaan freies ermessen bagi para pejabat, adalah pemahaman berkait dengan akibat hukum. Bahwa sebagaimana diuraikan di atas, bahwa sangalah mungkin freies ermessen itu termasuk dalam tindakan melampaui wewenang atau mencampuradukkan wewenang yang dapat berakibat bahwa freies ermessen tersebut menjadi tidak sah atau dapat dibatalkan.

Adapun yang dikategorikan melampaui wewenang sebagaimana diatur dalam Pasal Undang-Undang Nomor 30 Tahun 2014 tentang Administrasi Pemerintahan adalah jika freies ermessen atau diskresi itu dilakukan dengan melampaui batas waktu dan batas wilayah berlakunya wewenang yang diberikan oleh ketentuan peraturan perundang-undangan, dan hal ini menimbulkan akibat hukum bahwa hal tersebut adalah tidak sah.

Sementara Pasal 31 Undang-Undang Nomor 30 Tahun 2014 tentang Administrasi Pemerint aha $\mathrm{n}$ m enguraik an bahw a penggunaan freies ermessen atau diskresi termasuk dalam kategori mencampuradukkan wewenang jika tidak sesuai dengan tujuan wewenang yang diberikan dan bertentangan de ng a n de ng a n A s a s - as a s U m u m Pemerintahan yang Baik (AUPB)

Berkait dengan Asas-asas Umum Pemerintahan yang Baik (AUPB) sebagai salah satu filter freies ermessen, keberadaannya menjadi hal sangat diperlukan, supaya freies ermessen 
tersebut tidak sia-sia tapi justru bermanfaat bagi masyarakat luas sesuai maksud diberikannya kewenangan tersebut. Sebagai wujud keseriusan pemerintah dalam upaya memberikan layanan yang terbaik bagi masyarakat, mengingat bahwa pada dasarnya pejabat adalah pelayanan masyarakat yang wajib memberikan pelayanan publik yang baik. Mengingat bahwa, yang dimaksud pelayanan publik meliputi hal yang sangat luas, sebagaimana diuraikan dalam Pasal 1 ayat (1) Undang-Undang Nomor 25 Tahun 2009 tentang Pelayanan Publik, bahwa : "Pelayanan publik adalah kegiatan atau rangkaian kegiatan dalam rangka pemenuhan $\mathrm{k}$ ebutuhan pelayanan sesuai dengan peraturan perundang-undangan bagi setiap warga negara dan penduduk atas barang, jasa, dan/ atau pelayanan administratif yang disediakan oleh penyelenggara pelayanan publik." AUPB yang berawal dari hasil penelitian oleh Komisi De' Monchy tahun 1950 dan dilanjutkan oleh Komisi Vander Grinten tahun 1952 dengan istilah Algemene Beginselen van Behoorlijke Bestuur, (H.A Muin Fahmal, 2006: 49) Indonesia telah mengadopsi sebagaimana tercantum dalam Pasal 10 Undang-Undang Nomor 30 Tahun 2014 tentang Administrasi Pemerintahan, yang meliputi asas: 1) kepastian hukum, 2) kemanfaatan, 3) ketidakberpihakan, 4) kecermatan, 5) tidak menyalahgunakan wewenang, 6) keterbukaan, 7) kepentingn umum, 8) pelayanan yang baik.

Diterapkannya AUPB pada pembuatan freies ermessen tidak lain adalah dalam rangka mewujudkan pelayanan yang baik dari pejabat kepada masyarakat luas. Penggunaan freies ermessen dalam bentuk tertulis akan melahirkan peraturan kebijaksanaan (beleidsregel; policy rule) yang bertujuan menampakkan ke luar suatu kebijakan tertulis yang bisa berupa peraturan, pedoman, pengumuman, surat edaran. (Philipus M. Hadjon, 2011: 152). Adapun ciri-ciri peraturan kebijaksanaan (beleidsregel) menurut Bagir Manan sebagimana dikutip oleh Nomensen Sinamo adalah (Nomenson Sinamo, 2012):

a. Peraturan kebijakan bukan merupakan peraturan perundang-undangan.

b. Asas-asas pembatasan dan pengujian terhadap peraturan perundangan tidak dapat diberlakukan pada peraturan kebijaksanaan.

c. Peraturan kebijaksanaan tidak dapat diuji secara wetmatigheid.

d. Peraturan kebijaksanaan dibuat berdasarkan freies ermessen dan ketiadaan wewenang administrasi negara tersebut untuk membuat peraturan perundangan.

e. Batu ujinya adalah AUPB.

f. Bentuknya dapat berupa keputusan, instruksi, surat edaran, pegumuman, peraturan. 
Berdasar uraian di atas, pendayagunaan freies ermessen pejabatpemerintahan perlu dibarengi dengan keberadaan sarana kontrol, yang dapat meliputi kontrol yudisial, kontrol politik, kontrol administratif.

Dalam kontrol yudisial, sekalipun pengujian freies ermessen mendasarkan pada doelmatigheid, yang mana pengadilan tidak berwenang dalam hal ini, namun jika freiesermessen tersebut mengandung unsur penyalahgunaan wewenang atau sewenang-wenang, maka pengadilan dapat masuk dalam permasalahan ini, kecuali hal tersebut berkait dengan isu efisiensi dan efektivitas. Kontrol politik yang dimaksud di sini adalah kontrol yang dilakukan oleh DPR sesuai dengan Pasal 20A Ayat (1) Undang-Undang Dasar Negara Republik Indonesia Tahun 1945, bahwa “ Dewan Perwakilan Rakyat memiliki fungsi legislasi, fungsi anggaran, dan fungsi pengawasan." Adapun output dari kontrol politik adalah perbaikan kebijakan di masa depan. Sementara itu, dalam kontrol administratif, di Indonesia dikenal adanya upaya administratif sebagaimaa diatur dalam Pasal 48 Undang-Undang Nomor 5 Tahun 1986 tentang Peradilan Tata Usaha Negara, yang meliputi keberatan dan banding administratif.

\section{Penutup}

Pendayagunaan $f$ reies ermes sen oleh pejabat pemerintahan dalam rangka usaha untuk memujudkan kesejahteraan masyarakat sesuai dengan tujuan negara tercapainya masyarakat yang adil, makmur dan sejahtera, dalam pelaksanaannya harus mendapat pengawalan baik dari unsur-unsur yang membatasai freies ermessen itu sendiri, maupun penerapan AUPB sebagai pendamping. Di samping itu, keberadan lembaga kontrol juga sangat dibutuhkan supaya tidak terjadi tindakan penyalahgunan wewenang maupun tidakan yang sewenang-wenang, yang mana hal tersebut merupakan awal dari terjadinya maladministrasi.

\section{Daftar Pustaka}

Atmosudirdjo, Prajudi. 1981. Hukum Administrasi Negara. Jakarta: Ghalia Indonesia.

Budihardjo, Miriam. 2012. Dasar-Dasar Ilmu Politik. edisi revisi. cet kelima. Jakarta: Gramedia Pustaka Utama.

Darumurti, Krishna D. 2012. Kekuasaan Diskresi Pemerintah. Bandung: PT Citra Aditya Bakti.

Fahmal,H.A Muin. 2006. Peran Asas-asas Umum Pemerintahan yang Layak daam Mewujudkan Pemer-intahan yang Bersih. Yogyakarta: UII Press.

Hadjon, Philipus M. 2011. Pengantar Hukum Administrasi Indonesia. Introduction to the Indonesian Administrative Law. Yogyakarta: Gadjah Mada University Press. 
HR, Ridwan. 2003. Hukum Administrasi Negara. Yogyakarta: UII Press.

Marbun, S.F. 2012. Hukum Administrasi Negara I. Yogyakarta: UII Press.

Marbun, S.F. dkk (penyunting). Dimensi-Dimesi Pemikiran Hukum Administrasi Negara. Yogyakarta: UII Press.

Marbun,SF. 1988. Peradilan Tata Usaha Negara, Yogyakarta: Liberty Offset.

Nurtjahjo,Hendra. dkk. 2013. Memahami Maladministrasi. Jakarta: Ombudsman Republik Indonesia.

Palguna,I Dewa Gede. 2008. Mahkamah Konstitusi, Judicial Review, dan Welfre State. Jakarta: Sekre-tariat Jenderal dan Kepaniteraan Mahkamah Konstitusi.

Ridwan. 2014. Diskresi dan Tanggung Jawab Pemerintah. Yogyakarta: FH UII Press.

Sinamo, Nomenson. 2012. Hukum Administrasi Negara. Jakarta: Jala Perata Aksara.

\section{Peraturan-Perundang-Undangan:}

Undang-Undang Nomor 25 Tahun 2009 tentang Pelayanan Publik

Undang-Undang Nomor 30 Tahun 2014 tentang Administrasi Pemerintahan

Undang-Undang Nomor 37 Tahun 2007 tentang Ombudsman Republik Indonesia

Undang-Undang Nomor 5 Tahun 1986 tentang Peradilan Tata Usaha Negara 
